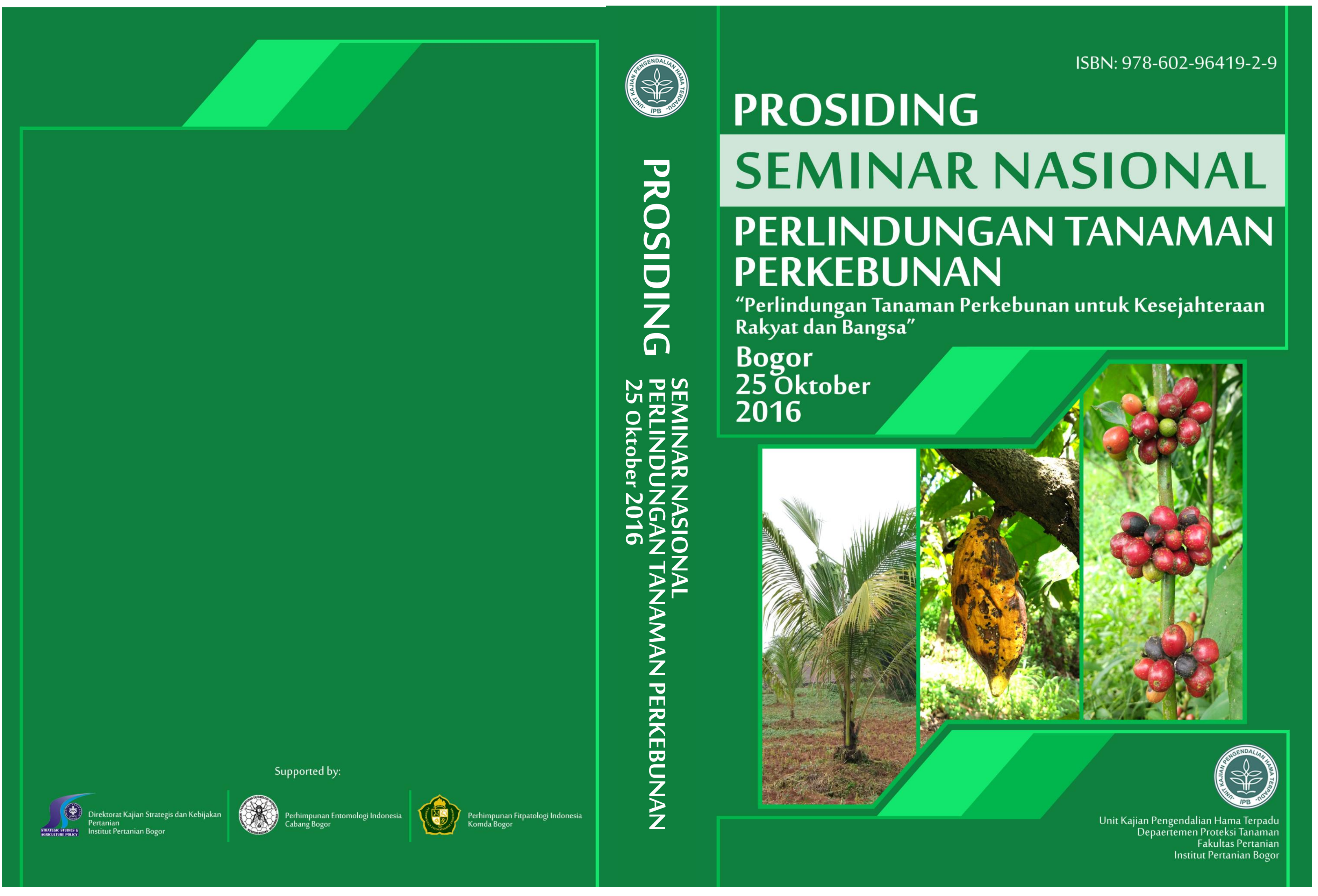




\section{PROSIDING}

\section{SEMINAR NASIONAL}

\section{PERLINDUNGAN TANAMAN PERKEBUNAN}

BOGOR, 25 OKTOBER 2016

Tema

"Perlindungan Tanaman Perkebunan untuk Kesejahteraan Rakyat dan Bangsa"

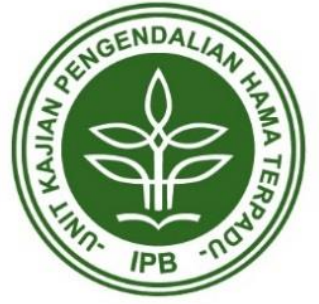

UNIT KAJIAN PENGENDALIAN HAMA TERPADU

DEPARTEMEN PROTEKSI TANAMAN

FAKULTAS PERTANIAN

INSTITUT PERTANIAN BOGOR

2017 


\title{
Tim Penyusun
}

\section{Reviewer:}
Ir. Djoko Prijono, MAgr.Sc
Dr. Ir. Purnama Hidayat, MSc
Dr. Ir. Abdul Munif, MSc.Agr
Dr. Ir. R. Yayi Munara Kusumah, MSi
Dra. Dewi Sartiami, MSi
Dr. Ir. Ruly Anwar, MSi
Dr. Efi Toding Tondok, SP., MSc.Agr
Dr. Ir. Supramana, MSi
Dr. Ir. Giyanto, MSi
Fitrianingrum Kurniawati, SP., MSi
Dr. Ir. I Wayan Winasa, MSi
Dr. Ir. Suryo Wiyono, MSc.Agr
Dr. Ir. Idham Sakti Harahap, MSi
Dr. Ir. Swastiko Priyambodo, MSi
Dr. Ir. Nina Maryana, MSi
Dr. Ir. Teguh Santoso, DEA
Dr. Ir. Pudjianto, MSi

\section{Penyunting Naskah}

Nadzirum Mubin, SP., MSi

Mahardika Gama Pradana, SP

\section{Layout}

Nadzirum Mubin, SP., MSi

\section{Desain Sampul}

Suryadi, SP

\author{
Ucapan Terima Kasih \\ Direktorat Kajian Strategis dan Kebijakan Pertanian (DKSKP) - IPB \\ Perhimpunan Entomologi Indonesia (PEI) Cabang Bogor \\ Perhimpunan Fitopatologi Indonesia (PFI) Komda Bogor
}

\author{
UNIT KAJIAN PENGENDALIAN HAMA TERPADU \\ DEPARTEMEN PROTEKSI TANAMAN \\ FAKULTAS PERTANIAN \\ INSTITUT PERTANIAN BOGOR \\ Telp 0251-8629364; Faks 0251-8629362 \\ Email: pkpht.ipb@gmail.com
}




\title{
Keragaman Nematoda Parasit Tanaman pada Rizofer dan Akar Kina (Cinchona ledgeriana) di Gambung, Indonesia \\ (Diversity of Plant Parasitic Nematodes in Rhizosphere and Root of Quinine (Cinchona ledgeriana) at Gambung, Indonesia) \\ Ankardiansyah Pandu Pradana', Muhammad Firdaus Oktafiyanto', Deden Dewantara Eris ${ }^{1,2}$, dan Abdul Munif ${ }^{1}$ \\ 'Departemen Proteksi Tanaman, Institut Pertanian Bogor \\ ${ }^{2}$ Pusat Penelitian Bioteknologi dan Bioindustri Indonesia, Bogor \\ Email: abdulmunif@ipb.ac.id
}

\begin{abstract}
Quinine plant (Cinchona ledgeriana) is widely used in the industrial and pharmaceutical world because these plants contain high alkaloid compounds. In 1950, Szkolnik reported some nematodes that infect this plant in India and Java. Furthermore, in 1977, Koch also reported the development of nematode genus which associated with this plant. Since 1977 up to now there has been no update information about nematodes in quinine plant, especially in Indonesia. This study aimed to obtain information about nematode genus contained in rhizosphere and roots of quinine plants at the Gambung quinine field area, West Java, Indonesia. A total of 10 samples of rhizosphere soil and roots of quinine plants extracted from a depth of $10 \mathrm{~cm}$. Nematodes in soil samples were extracted using centrifugation- floatation methods, and nematodes in root samples were extracted using a mist chamber. The absolute population density and the frequency distribution were calculated from the successfully extracted nematodes. The results showed that plant parasitic nematodes in the rhizosphere of quinine plants are Helicotylenchus sp., Hoplolaimus sp., Meloidogyne sp., Pratylenchus sp., Radopholus sp., Tylenchus sp., and Xiphinema sp. In the quinine plant roots, there were 6 species of plant parasitic nematodes ie, Aphelenchoides sp., Helicotylenchus sp., Meloidogyne sp., Pratylenchus sp., Radopholus sp., and Tylenchus sp. Nematode of Xiphinema sp., Helicotylenchus sp., Meloidogyne sp., Pratylenchus sp., and Radopholus sp. has 100\% distribution in quinine plant.
\end{abstract}

Keywords: distribution, dominance, free-living nematodes, identification, survey

\section{PENDAHULUAN}

Tanaman kina (Cinchona ledgeriana) adalah salah satu tanaman perkebunan penting di Indonesia. Tanaman ini diketahui memproduksi 25 macam senyawa alkaloid (Brodie \& Udenfriend 1945; Song 2009). Empat jenis senyawa alkaloid yang sudah banyak dimanfaatkan dalam kehidupan manusia adalah sinkonidin $\left.\left(\mathrm{C}_{19} \mathrm{H}_{22} \mathrm{ON}\right)_{2}\right)$, kinidin $\left(\mathrm{C}_{20} \mathrm{H}_{24} \mathrm{O}_{2} \mathrm{~N}_{2}\right)$, 
sinkonin $\left(\mathrm{C}_{19} \mathrm{H}_{22} \mathrm{ON}_{2}\right)$, dan kinin $\left(\mathrm{C}_{2} \mathrm{OH}_{24} \mathrm{O}_{2} \mathrm{~N}_{2}\right)$ (Resnekov et al. 1971; Couture et al. 2001). Kinin dapat digunakan sebagai obat antimalaria, dan berfungsi untuk menormalkan denyut jantung yang tidak teratur (cardiac arythmic) (Onabanjo et al. 1970; Linz et al. 1995; Sharma 2003; Meragiaw \& Asfaw 2014). Kinin juga dapat dimanfaatkan dalam industri minuman sebagai flavoring agent karena rasanya yang pahit. Senyawa-senyawa alkaloid tersebut dapat ditemukan pada kulit batang kina (Mulder-Krieger et al. 1982; Dijkstra et al. 1989; Marcelli \& Hiemstra 2010).

Penyakit yang sering ditemui pada tanaman kina adalah kanker batang, dan kanker akar (Crandall 1947). Saat ini belum banyak laporan mengenai hama dan patogen pada tanaman kina, khususnya di Indonesia. Patogen sebagai salah satu faktor pembatas produksi tanaman perlu diperhatikan agar tidak menimbulkan ledakan penyakit. Usaha dalam mencegah terjadinya ledakan penyakit dapat diawali dengan identifikasi patogen yang ada di sekitar tanaman.

Nematoda parasit tanaman adalah salah satu patogen yang dapat membatasi produksi berbagai jenis tanaman (Dropkin 1969; Williamson \& Gleason 2003). Szkolnik (1950) melaporkan nematoda Heterodera marioni (Cornu) Godey menginfeksi akar tanaman kina di India dan di Jawa (Indonesia). Nematoda Tylenchorhynchus alatus (Cobb) Filipjev juga dilaporkan menginfeksi akar tanaman kina di Afrika. Nematoda lainnya yang dilaporkan menjadi patogen pada tanaman kina adalah Tylenchus coffeae Zimm, dan Dorylaimus sp. Selanjutnya Koch (1977) melaporkan tanaman kina yang pertumbuhannya terhambat pada akarnya terdapat nematoda Meloidogyne incognita, Pratylenchus sp., dan Helicotylenchus sp. Sejak tahun 1977 sampai saat ini belum terdapat pembaruan informasi mengenai fitonematoda pada tanaman kina, khususnya di Indonesia. Tujuan dari penelitian ini adalah untuk memperoleh informasi genus nematoda yang terdapat pada rizosfer dan akar tanaman kina di Gambung, Jawa Barat.

\section{BAHAN DAN METODE}

\section{Pengambilan Sampel Tanah}

Pengambilan sampel dilakukan secara acak pada lahan tanaman kina dengan ketinggian $1300 \mathrm{~m}$ dpl di Gambung, Jawa Barat. Sampel diambil dari lahan seluas $300 \mathrm{~m}^{2}$ yang telah ditanami kina selama lebih dari 10 tahun. Terdapat 10 titik pengambilan sampel yang ditentukan secara acak. Sebanyak $100 \mathrm{~mL}$ tanah dari setiap titik diambil menggunakan bor tanah dengan kedalaman $10 \mathrm{~cm}$.

Sampel tanah dimasukkan ke dalam kantong plastik dan disimpan pada kotak penyimpanan agar terlindung dari sinar matahari secara langsung. Sampel diletakkan pada kotak penyimpanan agar tidak terjadi pemadatan tanah yang dapat mempengaruhi hasil penelitian (Barker \& Campbell 1981). 


\section{Pengambilan Sampel Akar}

Sebanyak 500 g akar diambil dari 10 tanaman kina. Pengambilan akar dilakukan pada kedalaman $10 \mathrm{~cm}$ dari permukaan tanah tepat di bawah tajuk tanaman kina. Akar yang diambil adalah campuran akar muda dan akar tua. Sampel akar dimasukkan ke dalam kantong plastik agar terhindar dari sinar matahari secara langsung (Barker \& Campbell 1981).

\section{Ekstraksi Nematoda dari Tanah}

Ekstraksi dilakukan menggunakan metode floatasi-sentrifugasi. Sebanyak $100 \mathrm{~mL}$ tanah diambil dan dimasukkan ke dalam ember plastik A lalu ditambahkan air sampai volume $1000 \mathrm{~mL}$, diaduk dan dibiarkan selama 30 detik. Air kemudian dituang ke dalam ember plastik B dengan melewati saringan berukuran 20 mesh, 50 mesh, dan 500 mesh dengan kemiringan 30 derajat.

Suspensi nematoda pada saringan 500 mesh disentrifugasi dengan kecepatan 2500 rpm (rotation per minute) selama 5 menit. Supernatan di dalam tabung dibuang, lalu pelet yang tersisa dicampur dengan larutan gula 40\% kemudian pelet dikocok hingga bercampur dengan larutan gula. Suspensi tersebut kemudian disentrifugasi kembali dengan kecapatan 2000 rpm selama 1 menit. Suspensi disaring menggunakan saringan berukuran 500 mesh, lalu dibilas dengan air dan ditampung di dalam botol koleksi untuk diidentifikasi menggunakan mikroskop stereoskopik dengan perbesaran 400x (Hooper et al. 2005).

\section{Ekstraksi Nematoda dari Akar}

Sebayak $50 \mathrm{~g}$ akar dari masing-masing tanaman kina dicuci menggunakan air mengalir sampai bersih. Sampel akar kemudian dipotong dengan ukuran $\pm 1 \mathrm{~cm}$. Akar yang telah dipotong diletakkan di atas kain kasa dengan ukuran 50 mesh. Kain kasa yang berisi akar diletakkan di atas corong yang dibawahnya terdapat gelas penampung. Nematoda di akar diekstraksi menggunakan mist-chamber selama 7 hari (Hooper et al. 2005).

\section{Penghitungan Kerapatan Populasi Absolut (KPA) Nematoda}

Populasi nematoda dihitung menggunakan mikroskop stereoskopik dengan perbesaran 40x. Penghitungan dilakukan dari $1 \mathrm{~mL}$ suspensi, dan diulang sebanyak 5 kali. Rata-rata nematoda pada $1 \mathrm{~mL}$ suspensi dikalikan dengan total volume suspensi (Norton \& Norton 1978).

\section{Penghitungan Frekuensi Sebaran Nematoda}

Frekuensi sebaran nematoda dihitung dengan membagi jumlah sampel yang mengandung suatu genus nematoda dengan total sampel yang diamati (Norton \& Norton 1978). 


\section{Pembuatan Preparat Semi-Permanen}

Suspensi nematoda dimasukkan ke dalam botol kaca dan diberi larutan FAA $\left(90^{\circ} \mathrm{C}\right)$ dengan perbandingan 1:1 (v/v). Larutan laktofenol 0.03\% diteteskan di tengah gelas objek. Nematoda yang telah difiksasi menggunakan FAA dikait dan diletakkan di tengah kaca preparat, kemudian ditutup menggunakan cover glass.

\section{Identifikasi Nematoda}

Nematoda pada preparat semi-permanen diamati morfologinya menggunakan mikroskop cahaya dengan perbesaran 400x.

\section{HASIL DAN PEMBAHASAN}

\section{Kerapatan Populasi Absolut Nematoda Pada Rizosfer dan Akar Kina}

Nematoda parasit tanaman (NPT) telah dilaporkan menginfeksi berbagai tanaman, baik tanaman semusim maupun tanaman tahunan (Neher \& Campbell 1994). Infeksi nematoda Meloidogyne graminicola pada tanaman padi dilaporkan mampu menurunkan produksi padai 11\% sampai dengan 73\% (Padgham et al. 2004). Pada tanaman tahunan seperti kopi, kapas, nilam, dan lada infeksi NPT telah dilaporkan menyebabkan kehilangan hasil yang cukup besar (Trudgill 1991; Bertrand et al. 2000; Duong et al. 2012). Tanaman kehutanan yang memiliki struktur kuat juga terinfeksi oleh nematoda parasit tanaman. Infeksi oleh NPT tidak hanya menyebabkan kehilangan hasil, namun juga menyebabkan perubahan biokimia pada tanaman yang terinfeksi (Dropkin 1969; Giebel 1974; Kesba \& ElBeltagi 2012).

Nematoda hidup bebas (NHB) atau biasa disebut free living nematodes juga terdapat pada rizosfer tanaman. Keberadaan NHB dilaporkan menguntungkan bagi tanaman karena NHB merupakan salah satu mikroorganisme yang berperan dalam dekomposisi bahan organik (Rønn et al. 2015; Gebremikael et al. 2016). Neher (2001) menyatakan salah satu indikator tanah yang sehat dan subur adalah melimpahnya populasi NHB di tanah. Bacterialfeeding nematodes dilaporkan mampu menyediakan nitrogen di tanah dalam jumlah yang besar. Kehadiran nematoda tersebut berperan besar dalam proses mineralisasi, yaitu dengan melepaskan nitrogen yang terdapat di dalam tubuh nematoda dalam bentuk ammonium yang dapat dimanfaatkan oleh tanaman secara langsung (Buchan et al. 2013; Lingaraju \& Patil 2014). NHB dari genus Filenchus sp. diketahui dapat dimanfaatkan sebagai agens biokontrol karena dapat memakan hifa dari cendawan Fusarium oxysporum, Rhizoctonia solani, Chaetomium globosum, dan Coprinus cinereus (Okada et al. 2005). Nematoda dari genus Aphelenchus avenae juga dilaporkan sebagai agens biokontrol terhadap busuk akar akibat infeksi cendawan (Barnes et al. 1981).

Hasil penelitian menunjukkan pada rizosfer dan akar tanaman kina terdapat nematoda parasit tanaman dan nematoda hidup bebas. Populasi nematoda parasit tanaman pada rizosfer dan akar tanaman kina lebih tinggi 37.26\% dibandingkan populasi 
nematoda hidup bebas. Populasi nematoda hidup bebas di rizosfer juga diketahui lebih tinggi $85.10 \%$ dari populasi di akar. Lebih lanjut populasi nematoda parasit tanaman dan nematoda hidup bebas di rizosfer dan akar kina disajikan pada Tabel 1.

Tabel 1 Populasi nematoda parasit tanaman dan nematoda hidup bebas dari rizosfer dan akar tanaman kina di Gambung, Jawa Barat

\begin{tabular}{lcc}
\hline \multirow{2}{*}{ Jenis nematoda } & \multicolumn{2}{c}{ Populasi nematode (individu) } \\
\cline { 2 - 3 } & tanah & akar \\
\hline Nematoda parasit tanaman & $322 \pm 30$ & $202 \pm 38$ \\
Nematoda hidup bebas & $47 \pm 4$ & $7 \pm 4$ \\
\hline
\end{tabular}

\section{Keragaman Nematoda Parasit Tanaman}

Hasil penelitian menunjukkan terdapat 7 spesies nematoda parasit tanaman pada rizosfer tanaman kina. Genus nematoda yang ditemukan adalah Helicotylenchus sp., Hoplolaimus sp., Meloidogyne sp., Pratylenchus sp., Radopholus sp., Tylenchus sp., dan Xiphinema sp. Nematoda dari genus Xiphinema sp. diketahui memiliki dominasi tertinggi di rizosfer kina, dengan nilai dominasi 32.65\%, diikuti oleh Pratylenchus sp. (29.79\%), Helicotylenchus sp. (13.50\%), Meloidogyne sp. (11.19\%), Radopholus sp. (7.34\%), Hoplolaimus sp. (3.54\%), dan Tylenchus sp. (1.99\%). Populasi dari setiap genus NPT yang ditemukan di rizosfer kina terdapat pada Gambar 1.

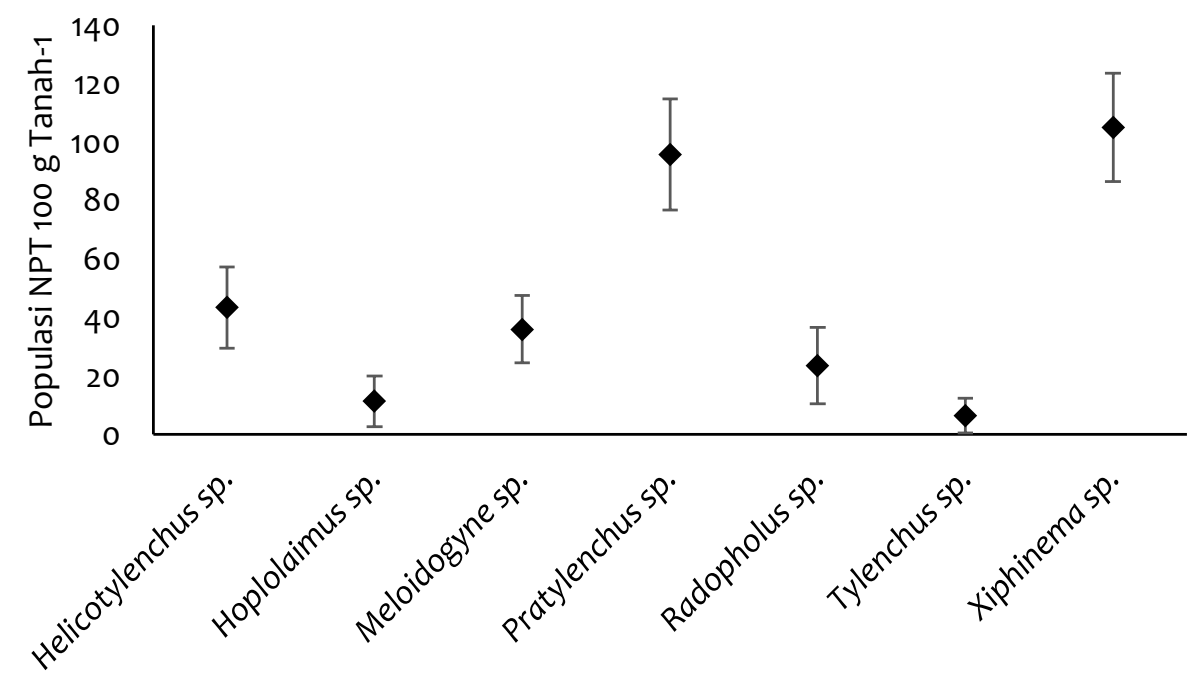

Spesies nematoda parasit tanaman

Gambar 1 Populasi nematoda parasit tanaman pada rizosfer tanaman kina di Gambung, Jawa Barat 
Hasil ekstraksi nematoda menunjukkan terdapat 6 genus nematoda parasit tanaman di dalam akar tanaman kina. Keenam genus tersebut adalah Aphelenchoides sp., Helicotylenchus sp., Meloidogyne sp., Pratylenchus sp., Radopholus sp., dan Tylenchus sp. Genus nematoda yang paling mendominasi adalah Pratylenchus sp. (32.82\%), diikuti oleh Meloidogyne sp. (21.93\%), Helicotylenchus sp. (15.74\%), Radopholus sp. (14.90\%)., Tylenchus sp. (7.52\%), dan Aphelenchoides sp. (7.08\%). Populasi nematoda dari akar tanaman kina disajikan pada Gambar 2.

Populasi Xiphinema sp. dan Pratylenchus sp. pada rizosfer tanaman kina perlu mendapat perhatian. Nematoda Xiphinema sp. adalah nematoda ekto-parasit yang beberapa spesiesnya merupakan vektor bagi virus tanaman. Sampai saat ini belum terdapat tanaman yang memiliki resistensi tinggi terhadap Xiphinema sp (Wang et al. 2002; AndretLink et al. 2004). Nematoda ini tersebar luas di seluruh dunia, terutama di daerah dengan iklim tropis. Xiphinema sp. dilaporkan menginfeksi tanaman tomat, anggur, pohon berkayu, anggur laut, pinus, lada, dan jeruk. Akar tanaman yang terinfeksi oleh nematoda ini akan berhenti tumbuh, sehingga menyebabkan tanaman menjadi merana karena tidak dapat menyerap nutrisi dengan maksimal. Gejala dari infeksi Xiphinema sp. adalah terdapat lesio pada akar, jumlah akar yang sangat sedikit, dan jaringan meristem akar menjadi hancur (Weischer 1975; Samota et al. 1994).

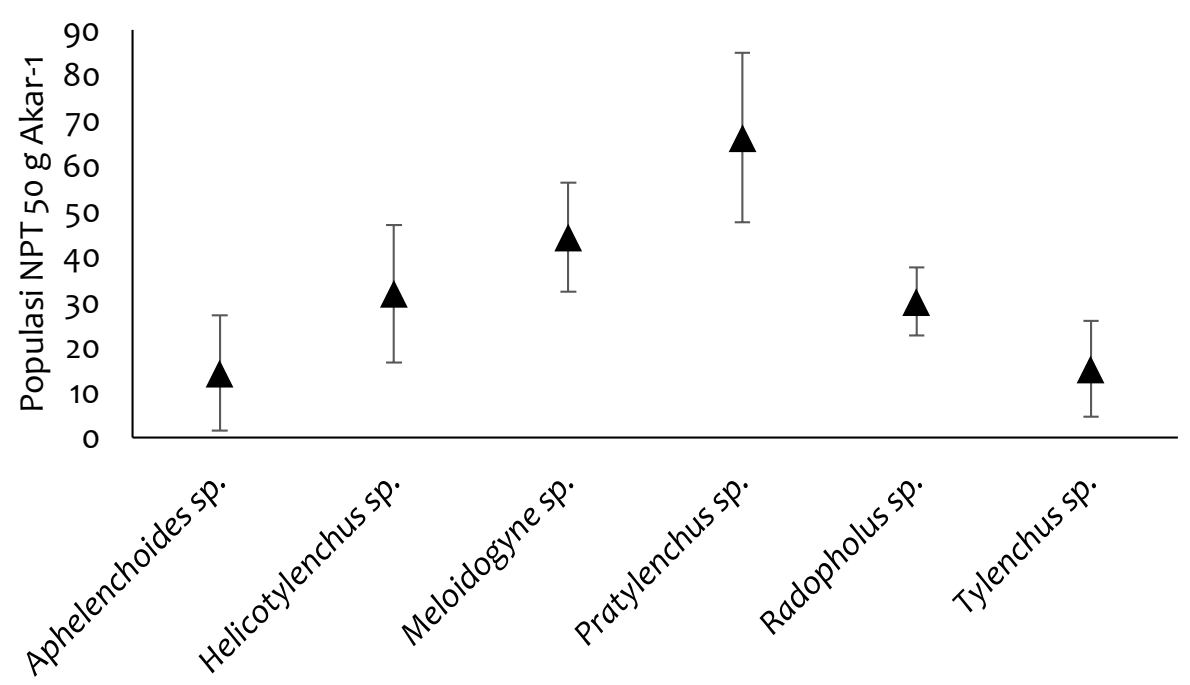

Spesies nematoda parasit tanaman

Gambar 2 Populasi nematoda parasit tanaman pada akar tanaman kina di Gambung, Jawa Barat

Pratylenchus sp. sebagai nematoda yang memiliki populasi tinggi pada rizosfer dan akar tanaman kina juga perlu mendapat perhatian. Beberapa tanaman seperti kopi, lada, kapas, pisang, jagung, gandum, dan kedelai merupakan inang Pratylenchus sp. Infeksi oleh Pratylenchus sp. menyebabkan kerusakan jaringan akar, yang akhirnya menyebabkan 
jaringan akar membusuk. Nematoda ini menginfeksi jaringan akar, kemudian berpindah di dalam akar dengan cara merusak sel-sel akar tanaman inang (Koen 1967; Senthilkumar et al. 2013; Forge et al. 2015; Zhang et al. 2015).

Kehadiran nematoda dari genus selain Xiphinema sp. dan Pratylenchus sp. dapat menyebabkan tanaman tidak dapat tumbuh dengan maksimal. Meskipun beberapa genus memiliki populasi yang cukup tinggi, namun kerusakan yang disebabkan oleh nematoda tersebut tidak separah kedua genus di atas. Berdasarkan kajian bioekologi seluruh genus yang ditemui, maka genus Xiphinema sp. dan Pratylenchus sp. adalah nematoda parasit tanaman yang paling penting karena dapat menyebabkan kerugian yang cukup besar.

\section{Frekuensi Sebaran Nematoda}

Hasil penelitian menunjukkan tidak seluruh genus ditemukan pada setiap sampel. Nematoda yang memiliki sebaran paling luas di rizosfer kina adalah Xiphinema sp., Pratylenchus sp., Meloidogyne sp., dan Helicotylenchus sp. dengan nilai sebaran 100\%. Nematoda lainnya dari genus Hoplolaimus sp.dan Radopholus sp. diketahui memiliki sebaran 90\%, dan Tylenchus sp. dengan nilai sebaran 70\% (Gambar 3).

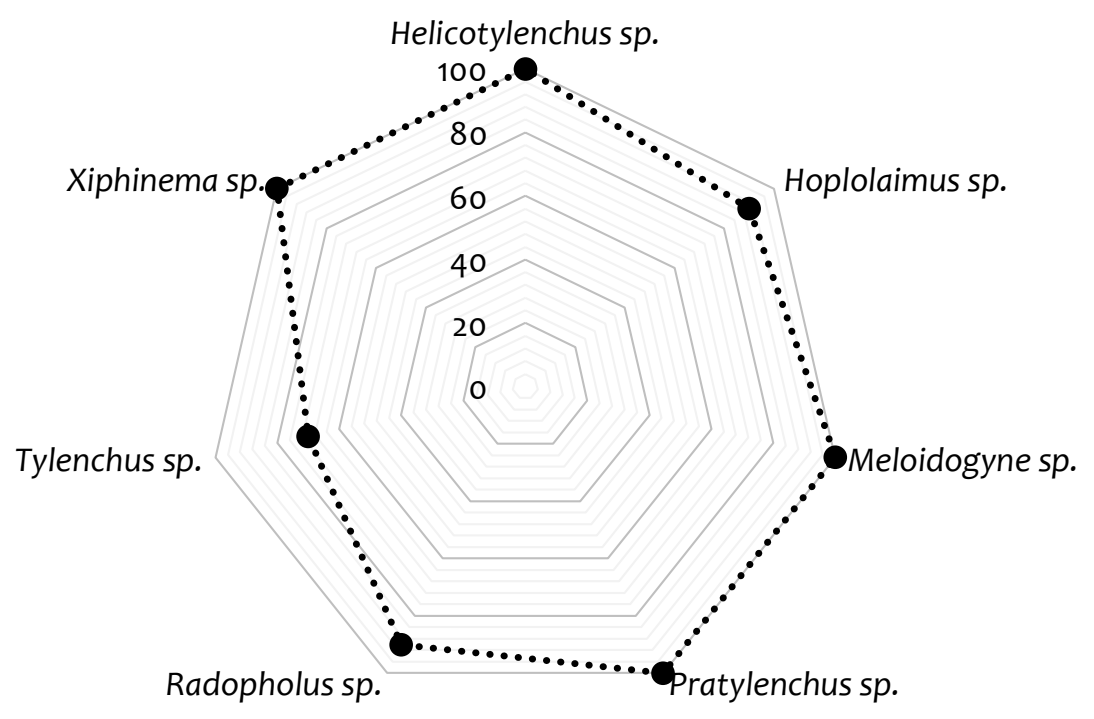

Gambar 3 Sebaran nematoda parasit tanaman pada rizosfer tanaman kina di Gambung, Jawa Barat

Sebaran nematoda pada akar tanaman kina didominasi oleh Pratylenchus sp., Meloidogyne sp., Helicotylenchus sp., dan Radopholus sp dengan nilai sebaran 100\%. Nematoda dari genus Tylenchus sp. ditemui pada $80 \%$ sampel akar tanaman kina, dan genus Aphelenchoides sp. ditemui pada 60\% sampel akar tanaman kina. Lebih lanjut sebaran nematoda parasit tanaman pada akar tanaman kina terdapat pada Gambar 4. 


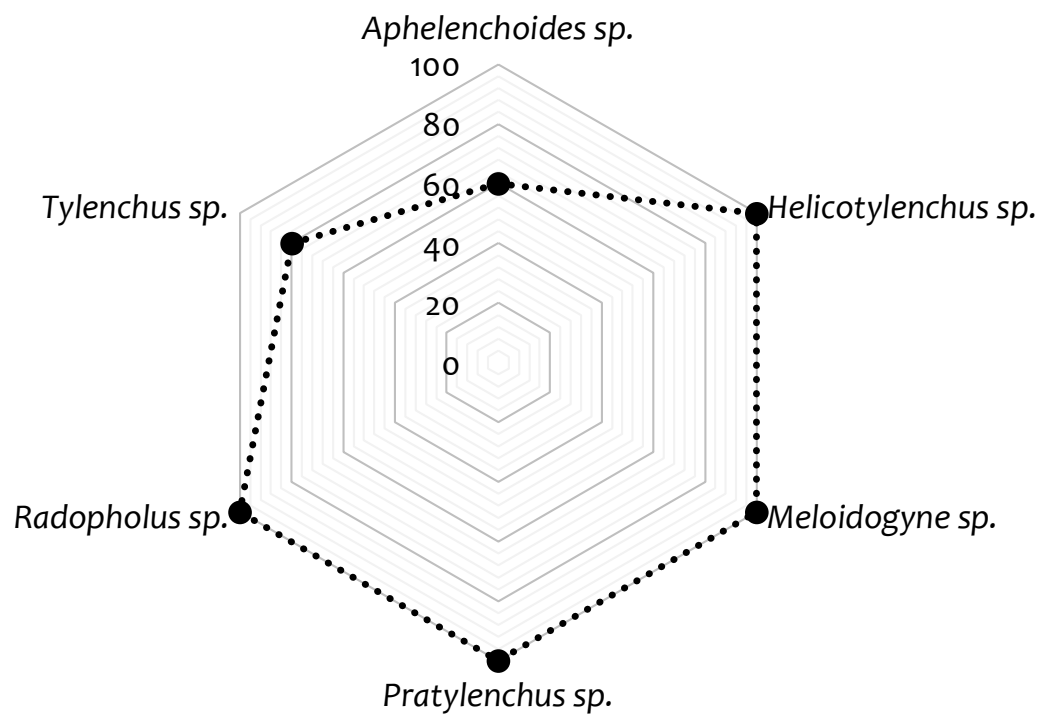

Gambar 4 Sebaran nematoda parasit tanaman pada akar tanaman kina di Gambung, Jawa Barat

Penyebaran nematoda pada suatu daerah sangat dipengaruhi oleh iklim makro dan mikro pada daerah tersebut. Selain pengaruh iklim, jenis tanaman dan kestabilan ekosistem juga sangat mempengaruhi keragaman nematoda. Lingkungan yang stabil, memiliki tanaman yang beragam biasanya memiliki keragaman jenis nematoda yang tinggi. Berdasarkan hasil pengamatan diketahui beberapa genus nematoda menyebar di seluruh lahan pengambilan sampel. Penyebaran tersebut dapat dipengaruhi karena nematoda dari genus di atas memiliki banyak inang, atau dapat bertahan di tanah tanpa adanya inang dalam waktu yang lama (Sohlenius \& Sandor 1987; Matlack 2001; Ou et al. 2005; Poage et al. 2008).

\section{KESIMPULAN}

Terdapat 7 genus nematoda parasit tanaman pada rizosfer tanaman kina yaitu, Helicotylenchus sp., Hoplolaiumus sp., Meloidogyne sp., Pratylenchus sp., Radopholus sp., Tylenchus sp., dan Xiphinema sp. Pada akar tanaman kina terdapat 6 genus nematoda parasit tanaman, yaitu Aphelenchoides sp., Helicotylenchus sp., Meloidogyne sp., Pratylenchus sp., Radopholus sp., dan Tylenchus sp.

\section{DAFTAR PUSTAKA}

Andret-Link P, Schmitt-Keichinger C, Demangeat G, Komar V, Fuchs M. 2004. The specific transmission of Grapevine fanleaf virus by its nematode vector Xiphinema index is solely determined by the viral coat protein. Virology. 320(1):12-22. Doi: 10.1016/j.virol.2003.11.022. 
Barker K, Campbell C. 1981. Sampling nematode populations. Di dalam: Zuckerman BM, Rohde RA, editor. Plant Parasitic Nematodes Volume III. New York (USA): Academic Press. hlm.451-474.

Barnes G, Russell C, Foster W, McNew R. 1981. Aphelenchus avenae, a potential biological control agent for root rot fungi. Plant Disease. 65:423-424.

Bertrand B, Nunez C, Sarah JL. 2000. Disease complex in coffee involving Meloidogyne arabicida and Fusarium oxysporum. Plant Pathology. 49(3):383-388. Doi: 10.1046/j.1365-3059.2000.00456.x.

Brodie BB, Udenfriend S. 1945. The estimation of basic organic compounds and a technique for the appraisal of specificity application to the cinchona alkaloids. Journal of Biological Chemistry. 158(3):705-714.

Buchan D, Gebremikael MT, Ameloot N, Sleutel S, De Neve S. 2013. The effect of free-living nematodes on nitrogen mineralisation in undisturbed and disturbed soil cores. Soil Biology and Biochemistry. 60:142-155. Doi: 10.1016/j.soilbio.2013.01.022.

Couture R, Harrisson M, Vianna RM, Cloutier F. 2001. Kinin receptors in pain and inflammation. European Journal of Pharmacology. 429(1):161-176. Doi: 10.1016/So0142999(01)01318-8.

Crandall BS. 1947. A new Phytophthora causing root and collar rot of cinchona in Peru. Mycologia. 39(2):218-223. Doi: 10.2307/3755010.

Dijkstra GD, Kellogg RM, Wynberg H, Svendsen JS, Marko I, Sharpless KB. 1989. Conformational study of cinchona alkaloids, A combined NMR, molecular mechanics and x-ray approach. Journal of the American Chemical Society. 111(21):8069-8076. Doi: 10.1021/ja00203a001.

Dropkin VH. 1969. Cellular responses of plants to nematode infections. Annual Review of Phytopathology. 7(1):101-122. Doi: 10.1146/annurev. py.07.090169.000533.

Duong DH, Bui TTN, Tran TDT, Nguyen TMP, Nguyen HH, Nguyen VT. 2012. Analysing the characteristics of soil nematode communities at pepper (Piper nigrum L.) cultivation area in Loc Hung commune, Loc Ninh district, Binh Phuoc province. Journal of Vietnamese Environment. 3(2):60-65.

Forge TA, Larney FJ, Kawchuk LM, Pearson DC, Koch C, Blackshaw RE. 2015. Crop rotation effects on Pratylenchus neglectus populations in the root zone of irrigated potatoes in southern Alberta. Canadian Journal of Plant Pathology. 37(3):363-368. Doi: 10.1080/07060661.2015.1066864.

Gebremikael MT, Steel H, Buchan D, Bert W, De Neve S. 2016. Nematodes enhance plant growth and nutrient uptake under $C$ and N-rich conditions. Scientific Reports. 6:1-10. Doi: $10.1038 /$ srep32862.

Giebel J. 1974. Biochemical mechanisms of plant resistance to nematodes: A review. Journal of Nematology 6(4):175-184. 
Hooper DJ, Hallmann J, Subbotin SA. 2005. Methods for extraction, processing and detection of plant and soil nematodes. Di dalam: Luc M, Sikora RA, Bridge J, editor. Plant Parasitic Nematodes in Subtropical and Tropical Agriculture Volume 2. Wallingford (UK): Cabi Publishing. hlm. 53-86.

Kesba HH, El-Beltagi HS. 2012. Biochemical changes in grape rootstocks resulted from humic acid treatments in relation to nematode infection. Asian Pacific Journal of Tropical Biomedicine. 2(4):287-293. Doi: 10.1016/S2221-1691(12)60024-0.

Koch VJM. 1977. Nematodes in cinchona. Di dalam: Prosiding Simposium Kina, Gambung (Indonesia), 9 Aug 1977. hlm. 179-184.

Koen H. 1967. Notes on the host range, ecology and population dynamics of Pratylenchus brachyurus. Nematologica. 13(1):118-124. Doi: 10.1163/187529267X01002.

Lingaraju S, Patil P. 2014. Nitrogen mineralization by bacterial feeding nematodes in different cropping systems. Trends in Biosciences. 7(1):29-32.

Linz W, Wiemer G, Gohlke P, Unger T, Schölkens B. 1995. Contribution of kinins to the cardiovascular actions of angiotensin-converting enzyme inhibitors. Pharmacological Reviews. 47(1):25-49.

Marcelli T, Hiemstra H. 2010. Cinchona alkaloids in asymmetric organocatalysis. Synthesis. 8:1229-1279.

Matlack GR. 2001. Factors determining the distribution of soil nematodes in a commercial forest landscape. Forest Ecology and Management. 146(1):129-143. Doi: 10.1016/S03781127(00)00454-0.

Meragiaw M, Asfaw Z. 2014. Review of antimalarial, pesticidal and repellent plants in the Ethiopian traditional herbal medicine. Journal of Herbal Science. 3(3):21-45.

Mulder-Krieger T, Verpoorte R, De Water A, Van Gessel M, Van Oeveren B, Svendsen AB. 1982. Identification of the alkaloids and anthraquinones in Cinchona ledgeriana callus cultures. Planta Medica. 46(09):19-24.

Neher DA. 2001. Role of nematodes in soil health and their use as indicators. Journal of Nematology 33(4):161-168.

Neher DA, Campbell CL. 1994. Nematode communities and microbial biomass in soils with annual and perennial crops. Applied Soil Ecology. 1(1):17-28. Doi: 10.1016/09291393(94)90020-5.

Norton DC, Norton D. 1978. Ecology of plant-parasitic nematodes. New York (USA): Willey. Okada H, Harada H, Kadota I. 2005. Fungal-feeding habits of six nematode isolates in the genus Filenchus. Soil Biology and Biochemistry. 37(6):1113-1120. Doi: 10.1016/j.soilbio.2004.11.010.

Onabanjo A, Bhabani A, Maegraith B. 1970. The significance of kinin-destroying enzymes activity in Plasmodium knowlesi malarial infection. British Journal of Experimental Pathology. 51(5):534-540. 
Ou W, Liang W, Jiang Y, Li Q, Wen D. 2005. Vertical distribution of soil nematodes under different land use types in an aquic brown soil. Pedobiologia. 49(2):139-148. Doi: 10.1016/j.pedobi.2004.10.001.

Padgham J, Duxbury J, Mazid A, Abawi G, Hossain M. 2004. Yield loss caused by Meloidogyne graminicola on lowland rainfed rice in Bangladesh. Journal of Nematology 36(1):42-48.

Poage MA, Barrett JE, Virginia RA, Wall DH. 2008. The influence of soil geochemistry on nematode distribution, McMurdo Dry Valleys, Antarctica. Arctic, Antarctic, and Alpine Research. 40(1):119-128. Doi: 10.1657/1523-0430(06-051)[POAGE]2.0.CO;2

Resnekov L, Gibson D, Waich S, Muir J, McDonald L. 1971. Sustained-release quinidine (Kinidin Durules) in maintaining sinus rhythm after electroversion of atrial dysrhythmias. British Heart Journal. 33(2):220.

Rønn R, Vestergård M, Ekelund F. 2015. Interactions between bacteria, protozoa and nematodes in soil. Acta Protozoologica. 51(3):223-235. Doi: 10.4467/16890027AP.12.018.0764.

Samota D, Ivezic M, Raspudic E. 1994. Ecology of Xiphinema vuittenezi and Xiphinema pachtaicum in vineyards of north-east Croatia1. EPPO Bulletin. 24(2):375-381. Doi: 10.1111/j.1365-2338.1994.tb01393.x.

Senthilkumar P, Nagesvari K, Revathi E, Prabhu S. 2013. Reaction of coffee plants against lesion nematode, Pratylenchus coffeae treated with bacterial consortium under Hilly regions of Shervaroys. Indian Journal of Nematology 43(2):152-155.

Sharma JN. 2003. Does the kinin system mediate in cardiovascular abnormalities? An overview. The Journal of Clinical Pharmacology. 43(11):1187-1195. Doi: 10.1177/0091270003258171.

Sohlenius B, Sandor A. 1987. Vertical distribution of nematodes in arable soil under grass (Festuca pratensis) and barley (Hordeum distichum). Biology and Fertility of Soils. 3(12):19-25. Doi: 10.1007/BFo0260574.

Song CE. 2009. Cinchona Alkaloids in Synthesis and Catalysis: Ligands, Immobilization and Organocatalysis. New York (USA): Willey.

Szkolnik M. 1950. Nematode root knot of cinchona in the Western Hemisphere. Plant Disease Reporter. 34(10):305-305.

Trudgill D. 1991. Resistance to and tolerance of plant parasitic nematodes in plants. Annual Review of Phytopathology. 29(1):167-192. Doi: 10.1146/annurev.py.29.090191.001123

Wang S, Gergerich RC, Wickizer SL, Kim KS. 2002. Localization of transmissible and nontransmissible viruses in the vector nematode Xiphinema americanum. Phytopathology. 92(6):646-653. Doi: 10.1094/PHYTO.2002.92.6.646.

Weischer B. 1975. Ecology of Xiphinema and Longidorus. Di dalam: Lamberti F, Taylor CE, Seinhorst JW, editor. Nematode Vectors of Plant Viruses. New York (USA): Springer. hlm 291-307. 
Williamson VM, Gleason CA. 2003. Plant-nematode interactions. Current Opinion in Plant Biology. 6(4):327-333. Doi: 10.1016/S1369-5266(03)00059-1.

Zhang F, Yan S, Zhou Y, Guo G, Guo S, Jin Z, Zeng H, Peng D, Ruan L, Sun M. 2015. First Report of Pratylenchus goodeyi on Banana in Hainan Province, China. Plant Disease. 99(5):731-731. Doi: 10.1094/PDIS-08-14-0874-PDN. 